\title{
A Study of Organizational Justice on the Trust in Organization under the Mediating Role of Ethical Leadership
}

\section{Hussam Al Halbusi}

PhD Candidate, Department of Business Strategy and Policy, Faculty of Business and Accountancy, University of Malaya, Kuala Lumpur, Malaysia

\section{Shehnaz Tehseen}

Lecturer, Department of Management, Sunway University Business School, Sunway University, Malaysia

\section{Fatima Amir Hammad Hamid}

Assistant Professor, Department of Business Administration, College of Science and Humanities-Hawta, Majmaah University, Majmaah, Saudi Arabia

\section{Asyraf Afthanorhan}

Lecturer, Faculty of Economics and Management Sciences, University Sultan Zainal Abidin (Unisza), Malaysia

\begin{abstract}
While previous sources of literature have proven the importance of justice, procedural, distributive and interactions are shown that have a greater impact on employees in the workplace. This paper summarizes the arguments and counterarguments within the scientific discussion on the issue of organizational justice as important predictors for many outcomes for individuals' level and organization level. The main purpose of the research is to investigate the association between justice and trust in the organization. Further, this study identified ethical leadership as an essential mechanism on this relationship between organizational justice and trust in the organization. The relevance of the decision of this scientific problem is that lack of trust in the workplaces. Investigation of the topic has predetermined several procedures and is carried out in the paper in the following logical sequence. Methodological tools of the research methods were self-administered. The object of research is the chosen postgraduate students from various Universities in Malaysia Kuala Lumpur. Thus, the paper presents the results of an empirical analysis. The research empirically confirms and theoretically proves that a significant association between justice and trust in the organization, both an immediate and indirect indicator of organizational justice identified with trust and through ethical leadership (EL). Distributive justice is connected in an indirect way to trust of an organization through ethical leadership and directly to trust in the organization. As was expected procedural justice is directly connected to the trust in the organization and organizational justice and ethical leadership have closer links.
\end{abstract}

Keywords: organizational justice, procedural justice, distributive justice, interactional justice, ethical leadership, trusts in the organization.

JEL Classification: D23, D63, L00.

Cite as: Al Halbusi, H., Tehseen, S., Hamid, F. A. H., Afthanorhan, A. (2018). A Study of Organizational Justice on the Trust in Organization under the Mediating Role of Ethical Leadership. Business Ethics and Leadership, 2(4), 89-98. http://doi.org/10.21272/bel.2(4).89-98.2018.

(C) The Authors, 2018. This article is published with open access at Sumy State University.

\section{Introduction}

To explain the phenomena such as trust and ethics, social exchange theory is the suitable choice for that aim (Blau, 1964). It is a critical piece of humanism and social understanding research (Homans, 1958; Thibaut \& Kelley, 1959) and it contains the premise of hypotheses in association conduct, for example, pioneer part employment (Gerstner \& Day, 1997; Graen \& Cashman, 1975; Liden \& Graen, 1980), leadership styles, for example, transformational leadership (Bass Bernard, 1985; Judge \& Piccolo, 2004), justice of the company (Adams, 1965; Bies, 1986; Folger \& Greenberg, 1985) and put stock in viewpoints (Dirks \& Ferrin, 2002). The overwhelming structure that social exchange comprises used to clarify an assortment of representative work attitudes (Colquitt, Conlon, Wesson, Porter, \& Ng, 2001; Dirks \& Ferrin, 2002; Rhoades \& Eisenberger, 2002; Richard, Ismail, Bhuian, \& Taylor, 2009). 
Fairness and trust are the two vital features of the social exchange theory since fair exchanges as a vital part of social instances of the social trade hypothesis ponders have researched the impression of equity issues including interactional, procedural, distributive and subordinate practices (Cohen-Charash \& Spector, 2001; Colquitt et al., 2001). Beside that fairness, and trust is a basic part of social exchanges (Blau, 1964). Trust is gotten through the corresponding communications among parties incorporates the relationships (Homans, 1958) and it is an essential component of exchange theory. Justice and trust in the organization are linked with each other (Aryee, Budhwar, \& Chen, 2002). Fair treatment will expand the level of the social exchange relationship, this will improve the connections between two gatherings. When workers perceive they are dealt with fairly in the choices and rewards (distributive justice) and put their voices in the clearing honest (process fairness) and exhibit that they have treated in a fair manner from the administration (interactional justice) and the trust will be produced among administrator and subordinates that would lead towards positive outcomes.

This examination has different issues. One is the imperative of the trust perspective connection amongst equity and employee's work antidotes (Blau, 1964), one of the points is to analyze to which degree organizational justice affects employee's level of trust in the working environment. Moreover, not many studies have inspected the three sorts of justice in one single investigation (Aryee et al., 2002; Camerman, Cropanzano, \& Vandenberghe, 2007; Roch \& Shanock, 2006). However, all these observational research uncovered those different sorts of organizational justice to be so vital in computing worker's attitudes (Cohen-Charash \& Spector, 2001; Colquitt et al., 2001). Truth is told to completely comprehend the social exchanges in one investigation think about the need to include. As of late, thinks about have shown that equity shapes are identified with the trust (Aryee et al., 2002; Dirks \& Ferrin, 2002; Stinglhamber, Cremer, \& Mercken, 2006).

In momentum look into a degree and explores the current discoveries by inspecting the relationship among organizational fairness and trust in the organization. By analyzing both trusts, and more significant comprehend to which degree decency recognition impact work results could be accomplished in a work environment.

This investigation makes an extra commitment by developing past examinations looking at the connection between organizational justice and trust by dissecting the part ethical leadership (EL) among justice and put stock in linkages. Studies have shown that the practices of pioneers, for example, moral conduct are related with organizational justice and trust (Demirtas, 2015; C. Li, Wu, Johnson, \& Wu, 2012; Y. Li, Xu, Tu, \& Lu, 2014).

Most past examinations have researched the connection between organizational justice and trust; however, moral was excluded as a component of the investigation. Next to, on account of these factors are much corresponded earlier research has examined the connection between saw bolster and organizational justice; however trust was excluded as a major aspect of the investigation. What's more, since these factors are much related, there are just a couple of studies have incorporated these whole factors (equity, moral, and trust) at that point demonstrates the requirement for additionally inquire about.

In this examination, the earlier investigations will be broadened by examining a model that explored the part of ethical leadership as go-between amongst equity and trust. In any case, not at all like earlier investigations each of the three types of equity was incorporated along as particular with moral and trust, consequently, this examination will be contemplated them all together and examining how ethical leadership intervenes this relationship.

The essential concentration of this exploration is examining the connection between these three factors organizational equity, ethical leadership and trust. Different examinations have demonstrated that the factors are parts to worker's attitudes, for example, work fulfillment (Dirks \& Ferrin, 2002; Valentine, Greller, \& Richtermeyer, 2006), Performance, responsibility, turnover intention (Aryee et al., 2002; Baker, Hunt, \& Andrews, 2006; Brashear, Manolis, \& Brooks, 2005; J. DeConinck \& Bachmann, 2005; Pappas \& Flaherty, 2008; Rhoades \& Eisenberger, 2002; Riggle, Edmondson, \& Hansen, 2009). Consequently, from all above past examinations understanding the relationship the factors can give different results to the association.

\section{Literature Review}

Humanist's specialists have guides (Blau, 1964; Homans, 1958) and social psychologists (Thibaut \& Kelley, 1959) these were the fundamental establishment of social exchanges theory. A large portion of the theory has used to find the associate among equity, moral, and trust these are Gained of exchange theory (Blau, 1964). In light of the (Blau, 1964), social exchange is "the voluntary actions of individuals that are motivated by the returns they are expected to bring and typically do in fact bring from others" (Blau, 1964: 91). 


\subsection{Organizational Justice}

Organizational justice is classified to three, procedural, distributive, and interactional justice judges for over 30 years have been concentrated on this territory (Cohen-Charash \& Spector, 2001; Colquitt et al., 2001; Cropanzano \& Greenberg, 1997). The three sorts of judges are identified with others, different examinations have demonstrated that the free in their relationship to subordinates states of mind (Colquitt et al., 2001).

The exploration of an organizational justice started with distributive equity the appearance of decency of results that workers got (Adams, 1965). The early research demonstrates that worker's feels of imbalance distributive are related with out of line, dissatisfaction with, for example, pay advancement of results (J. B. DeConinck \& Stilwell, 2004; Folger \& Konovsky, 1989).

One can characterize procedural equity that the procedure and procedural by that assignment choice are taken (Folger \& Greenberg, 1985; Thibaut \& Walker, 1975). A component part of procedural equity is that letting the members of information or voice in the results. In any case, regardless of the possibility that the results were unsuitable to adherents or members, and permits to the members to give their voices in procedural could limit a portion of the dissatisfactory. As opposed to since, distributive equity is identified with particular results like the compensation, procedural equity is more identified with organizational equity results such citizenship conduct, duty (Cohen-Charash \& Spector, 2001; Colquitt et al., 2001; Folger \& Konovsky, 1989; Masterson, Lewis, Goldman, \& Taylor, 2000).

Interactional equity depicts the level of treatment and relational relationship or saw of the fairness issues to which degree the representatives are dealt with in the association (Bies, 1986).

From different perspectives, the procedural equity, interactional equity contains lesser parts of cooperation. It incorporated the level of trustworthiness delicately and regards of the administration conduct with subordinates (Bies, 1986). The fundamental difference among procedural and interactional is the concentration of the view of equity or bad form. The appearance of procedural is more identified with the association. Though the appearance of interactional foul play is more to predominant (Masterson et al., 2000).

Essentially the justice energizes social exchanges relationships (Masterson et al., 2000; Roch \& Shanock, 2006). Blau (1964: 98) considers that "The foundation of exchanges relations includes making ventures that establish a sense of duty regarding the other party". The responsibility of the representatives will be higher to the organization when they saw that the treatments are reasonable. And in addition, they will answer the organization with a feeling of more inspirational manners (Colquitt et al., 2001).

As have noted before a few investigations have joined equity to various dispositions. Be that as it may, very little looks into have led the relationship among organizational justice and either moral leaders and trust, these factors are a part of social exchanges theory. The coming part will talk about the connection between equity and trust.

\subsection{Trust in Organization}

The expected of trusting is social relationship "since social exchanges are, for example, respond, the fundamental issue is to substantiate oneself dependable" Blau (1964: 98). In the social exchanges trust is one of the fundamental components since it gives an advantage from individual to others, when that trust accessible between gatherings will be responds trust is essential component of social exchanges since once personal gives a benefits issues to another someone else the assumption have to the return will respond the behave. Shared that will creation a trust and proceeds with the relationship and commitment (Blau, 1964; Homans, 1958).

For instance, when the dependable has done in the previous the desire of the reliable in the further future among gathering will exist. The significance of trust appeared in both inside organization and the relationship among associations (Gounaris, 2005; Johnson, Barksdale, \& Boles, 2003; Swan, Bowers, \& Richardson, 1999). In the social exchanges setting, if the subordinates saw the choices is reasonable then the presumption of workers the prospects choices will be reasonable. Along these lines, trust is influenced by the impression of representatives (Brockner, 1996). This examination has centered to test the connection of organization, fairness and trust. The later part will explain the relationship of two constructs.

\subsection{Organizational Justice and Trust in Organization}

View of trust and decency that will expand the trust in experts (Brockner, 1996). As supported (Mayer, Davis, \& Schoorman, 1995) by Mayer et al. (1995) and Leventhal, Karuza, \& Fry (1980) in their contention of trust and equity individually highlight the significance of consistency. For example, Mayer et al. (1995: 719) express 
that "such issues as the consistency of the gathering's past activities, conviction that the trustee has a solid feeling of equity and the degree to which the gathering's activities are harmonious with his or her words all influence how much the gathering is judged to have honesty". Thus, the basis of equity is comprehended to be an imperative of trust.

The past inquiries about have positive backings mentioned on the link among organizational justice and put stock in (Aryee et al., 2002; Aryee \& Chen, 2004; Stinglhamber et al., 2006). Furthermore, the uncovered of meta-examinations demonstrated that a huge connection between the segments from justices and with trust too (Cohen-Charash \& Spector, 2001; Colquitt et al., 2001; Dirks \& Ferrin, 2002). The significance of the above signs of how the two measurements impact different results. The analysis reveals that of the three distinct, only one (consisting of altruism and courtesy items) has influenced the trust (Hwa, M. A. C., \& Ramayah, T. (2010).

The examinations have given a critical understanding of these develops equity and trust, the existed writing. To begin with, just a couple of studies could be discovered that contains all type of equity and measures the trust (Aryee et al., 2002). Notwithstanding, the examinations uncovered that all the type of equity unmistakable factors (Cohen-Charash \& Spector, 2001; Colquitt et al., 2001) the amendment of trust are so higher (Dirks \& Ferrin, 2002).

The point of this examination is to degree on the past investigations by looking at the relationship among all these types of equity factors (i.e. procedural, distributive and interactional,) and trust. Also, following up the hypothesis will look at.

H-1.a: procedural justice will be positively related to trust in the organization.

H-1.b: Distributive justice will be positively related to trust in the organization.

H-1.c: Interactional justice will be positively related to the trust in the organization.

\subsection{Mediating Effect of Ethical Leadership}

The frame sorts of organizational fairness and recognizing them of analysts (Colquitt et al., 2001) the apparent from distribution fairness allude in the assignment of results, procedural justice depicts the procedure by how hierarchical assets are apportioned, interactional justice to which degree the administrator treated the subordinates.

The researchers (Cropanzano, Prehar, \& Chen, 2002; Loi, Yang, \& Diefendorff, 2009), recommended the above sorts of equity observation are two are respected to organization centered, since the asset is controlled by the organizational, for example, distribution choice and others systems. Interestingly interactional equity referring to the fairness and treatment, for example, the exactness of data and the execution of the methods. (Olkkonen \& Lipponen, 2006).

A few examinations (Kirkman, Chen, Farh, Chen, \& Lowe, 2009; Pillai, Schriesheim, \& Williams, 1999) contended that the urgent impacts of the pioneer on the worker's recognition are basic and essential organizational of fairness (i.e., procedural and distributive justice). The moral of the pioneer keep up and advances on the standard of morality in the working environment, for example, reasonableness one of the imperative desire their practices assume a critical part to influence the judgment of the strategies and outcomes of the organizational (Demirtas, 2015; C. Li et al., 2012; Y. Li et al., 2014). The investigation is proposed to look at the relationship among equity and trust by presenting the ethical leadership as a key intervening system.

Procedural justice is shown when worker input takes in thought amid the actualized and basic leadership forms are consistency in the choices, feeling concealment, and precision, rectify capacity, representativeness, and ethicality (Leventhal et al., 1980).

The desire of ethical leadership which employees could see, for example, open correspondence, tune in to representatives input and which they say and member in voice (Brown, Treviño, \& Harrison, 2005). The arrangements and practices that accentuation and adherence and draw the consideration of employees to the reasonableness systems of the organization (Loi, Lam, \& Chan, 2012). An investigation led by C. Li et al. (2012) has shown that adherents who in touch and under moral pioneer that has more prominent and saw of procedural justice. As recently conceptualized by Al Halbusi, H et al. (2017) Perception of organizational fairness significantly influence ethical leadership.

Bal, de Lange, Ybema, Jansen, and van der Velde (2011) Have noticed that trust has a basic part in procedural equity evaluation in a working environment. In light of the trust in the organization, the subordinates built up 
their confided in the organization; additionally, ethical leadership conduct has a positive effect on the representatives sentiment the thought processes and goal of the organization (Tyler, 1994).

Pillai et al. (1999), have highlighted when they have convictions that would take favorable circumstances excessively, thus they have a tendency to evaluate the strategies and methodology of the organization in a positive way (Wong, Wong, \& Ngo, 2012). The survey of the writing demonstrated the steady and noteworthy of these indicators. Depending on the examinations (Hoy \& Tarter, 2004; Lind, Tyler, \& Huo, 1997), the hypothesis created.

Leventhal (1976) Elude distributive justice that the proper standards are utilized in the assignment of the assets and rewards. The moral conduct of pioneer offer cases to which degree pioneer get things done in the right and right path in term of results dispersion of decency, and that controls of the reward moral, unscrupulous conduct in the working environment (Gini, 1997; Treviño, Brown, \& Hartman, 2003). The reward for help moral direct required unexpected with subordinate's view of distributive equity. Trust is basic and basic to create the observation and strengthen of distributive fairness of value for the adherents (Tan \& Tan, 2000). At the point when the subordinates have confided in the organization depended on the conduct of the pioneer, representatives will show and show inspiring dispositions, saw an impression of the organization (Dirks \& Ferrin, 2001). Since the representatives confide in their organization, in all probability will have solid principle and feeling that would match their interests. Along these lines, the representatives trust that the adjusting of the assets relying upon their qualities and commitments when the sense that the organization could be trusted (Konovsky \& Pugh, 1994). Past examinations have given altogether confirmations, for example, that trust in the work environment molded distributive equity impression of followers (Mansour-Cole \& Scott, 1998; Tyler, 1989, 1994). Predictable with earlier looks into and the arguments, the accompanying hypothesis has formulated.

H-2.a: Ethical leadership will be positively mediated the association between distributive justice and trust in the organization.

H-2.b: Ethical leadership will be positively mediated the association between procedural justice and trust.

H-2.c: Ethical leadership will be positively mediated the association between international justice and trust.

\subsection{Research Framework}

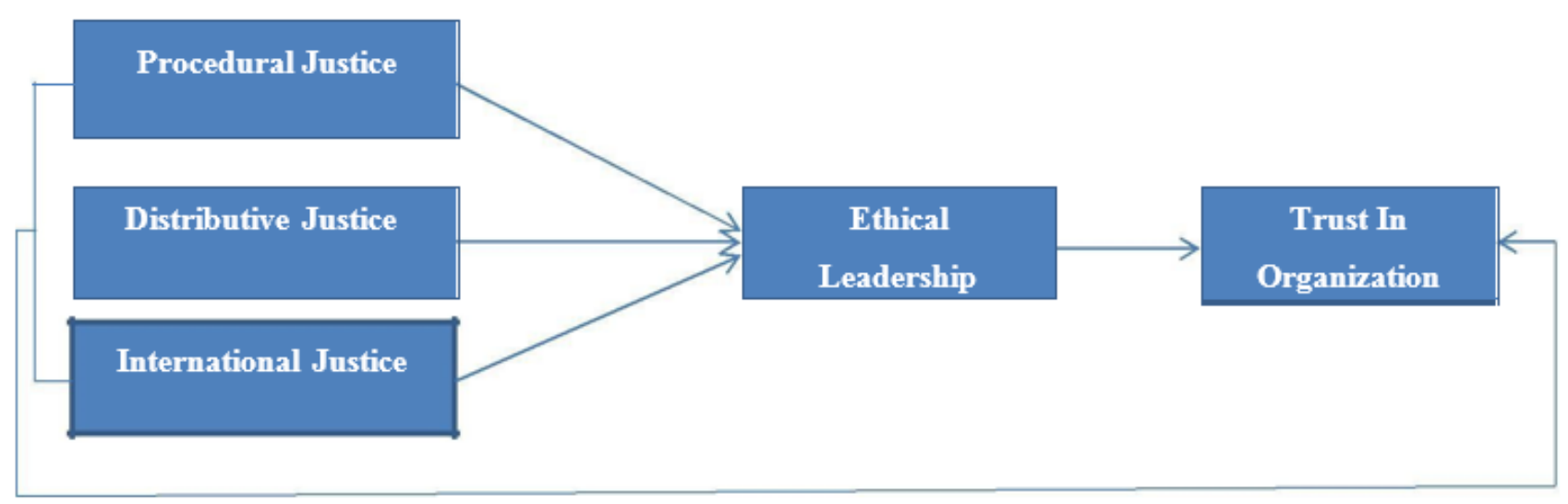

Figure 1. Research Framework

Source: Own elaboration

\section{Method}

\subsection{Sample and Procedures}

In this examination, the speculation tried, utilizing information gathered from $\mathrm{PhD}$ and master MBA and management students, from various universities in Malaysia: University of Malaya (UM), University Putra Malaysia (UPM), University Technology Malaysia (UTM), International Islamic University Malaysia (IIUM) Furthermore, ace's understudies examining in contrasts colleges in Malaysia Kuala Lumpur, understudies participated in the study. The survey has appropriated to the understudies for evaluated their view of the unrivaled ethical leadership (EL) behavior, and justices. The survey was connected with introductory letter explained the aims and nature of the study. Confidentiality has been certain the participants. About 250 of the 
surveys were distributed, around 194 returned, the response rates of assessing their inclination and conclusion with respect to drunkard put stock in, justice and ethical leadership behavior.

A sum of the 194 was restored, a few cases have evacuated which was missing numerous information, and 184 was the viable examples estimate the information to be examinations. The percent of the ages 50 percent were male, and the normal of residency matured were among 33 and 37, was $5.83(\mathrm{SD}=3.84$ ) also, 51 percent of them holding released male or more degree. Most of the members work in different divisions, for example, individual banking money, general responsibility, operations, electronic bank, and risk management official office.

\subsection{Measurement}

The Measures items were adapted, the majority of the scales set up with adequate legitimacy and unwavering quality. Every one of the builds was for the measurement of constructs by the five points Likert sorts with started from 1 (strongly disagree) to 5 (strongly agree).

\section{Ethical Leadership Behavior}

Ten items scale to give the employee's perceptions towards ethical leadership behavior as developed items was made by Brown et al. (2005). The participants have been asked to give their assessment and opinion to the rates to which extents they agreed with described of the statement towards superior's behavior. The sample of the items "My leader/manager can be trusted". Cronbach's alpha for this scale was 0.85 .

\section{Distributive Justice}

The measurement of distributive justice measured in items these items were developed by Colquitt et al. (2001) to measured employee's distributive justice example of this is "I am fairly rewarded for the amount of effort I put effort". Cronbach's alpha for this scale was 0.78 .

\section{Procedural Justice}

7-Items were measured the procedural justice, these items were developed by Colquitt et al. (2001) to evaluate the process and procedural justice. Such as sample of an item "My organization the process are designed to accurate information necessary for making performance appraisal". Cronbach's alpha for this scale was 0.84 .

\section{Interactional Justice}

The measurement of interactional justice was using three scales developed by Colquitt (2001). Scales Interactional Justice $(\alpha=0.74)$. A sample of the item "Was he or she candid in his or her communication with you".

\section{Trust in Organization}

7-Items scales developed by Robinson (1996). For measuring the employees to assess the trust in the organization. A sample of the item "In overall, I believe my employer's motives and intentions are good". Cronbach's alpha for this scale recorded at 0.71 .

\section{Results}

\subsection{Confirmatory Factor Analysis}

As shown in the stand 1. the discussed of the correlation, means and standard deviation have appeared. The primary stage in examination the measurements were to lead a confirmatory factor analysis (CFA) for the factors. Except for GFI and AGFI fit files, the consequences of the CFA demonstrated a decent model fit $(\mathrm{X} 2=943.04, \mathrm{DF}=671, \mathrm{p}=.00, \mathrm{GFI}=.81, \mathrm{AGFI}=.80, \mathrm{NFI}=.97, \mathrm{CFI}=.94, \mathrm{RMSEA}=.043, \mathrm{CI}=.034-.047)$.

\subsection{Structural Model}

The subsequent stage in dissecting the information was to test the hypothesis display. The outcomes showed a solid match by generally records $(\mathrm{X} 2=978.98, \mathrm{df}=681, \mathrm{p}=.00, \mathrm{GFI}=.84, \mathrm{AGFI}=.80, \mathrm{NFI}=.93, \mathrm{CPI}=.98$, RMSEA=.041, CI=.032.-407). According to hypothesis 1a, Procedural justice is related positively to trust. Support was found for this hypothesis $(\beta=.14$, NS). Support, however, was found for both hypothesis $1 \mathrm{~b}$ and hypothesis 1c. Distributive justice was related positively to trust in the organization $(\beta=.18, T=2.32, p=<.01)$ whereas interactional justice $(\beta=.39, \mathrm{t}=4.95, \mathrm{p}=<.01)$ positively to trust in the organization and much through 
ethical leadership. The consequences of the estimation demonstrate showed a solid match by most of the indices ( $\mathrm{x} 2=945.00, \mathrm{df}=681, \mathrm{p}=.00, \mathrm{GFI}=.87$, AGFI.80, NFI.94, CFI.97, RMSEA.044, CI.043-.051).

Additionally, the majority of the pointer factors stacked fundamentally on the estimated Factor.

Table 1. The correlation matrix, means, and slandered deviation

\begin{tabular}{|c|c|c|c|c|c|c|c|}
\hline Trust in the organization & .36 & & & & & \\
\hline Ethical leadership & .53 & .76 & & & & & \\
\hline Interactional Justice & .62 & .44 & .63 & .65 & & & \\
\hline Procedural Justice & .54 & .53 & .67 & .58 & .78 & & \\
\hline Distributive Justice & .32 & .36 & .45 & .57 & .32 & .47 & \\
\hline Means & 22.17 & 18.19 & 17.23 & 18.45 & 13.79 & 22.84 & 14.87 \\
\hline Standard deviations & 4.98 & 4.24 & 4.25 & 4.78 & 4.00 & 6.48 & 5.13 \\
\hline
\end{tabular}

Source: Own elaboration

The analysis of the ethical leadership was served as mediation the relation between the fairness and the trust in the organization the hypothesis was found the link and support were found $2 \mathrm{a}, 2 \mathrm{~b}$ and much with $2 \mathrm{c}$. Ethical leadership serves as mediated the association among procedural fairness and trust in the organization: procedural justice $\rightarrow$ ethical, leadership $(\beta=.43, \mathrm{~T}=5.64, \mathrm{p}=<.01)$ and Ethical leadership $\rightarrow$ trust in the organization $(\beta=.63, \mathrm{~T}=5.44, \mathrm{p}=<.01)$. As hypothesized $2 \mathrm{c}$ has stronger mediation as the two above between interactional justice and ethical leadership: interactional justice $\rightarrow$ ethical leadership $(\beta=.43, \mathrm{~T}=5.43, \mathrm{p}=<.01)$ and ethical leadership $\rightarrow$ to trust in the organization $(\beta=.05$, NS). Furthermore, hypothesis $2 \mathrm{c}$ was upheld much. In any case, the alteration indices demonstrated that distributive equity was connected emphatically to ethical leadership $(\beta=.36, \mathrm{~T}=6.35, \mathrm{p}=<.01)$. Ethical leadership has positively served the mediation part. The relationship between fairness and trust.

In the finding of the study, it is shown that justice is directly linked to trust in the organization and through ethical leadership indirectly. As the model has fit and the statistics shows on Table 2.

Table 2. The fit indices for the study

\begin{tabular}{|c|c|c|c|c|c|c|c|}
\hline CFA Model & 671 & 943.04 & .81 & .80 & .97 & .94 & .043 \\
\hline hypothesize & 681 & 978.98 & 84 & .80 & .93 & .98 & .041 \\
\hline Model & & & & & & & \\
\hline Final model & 681 & 945.00 & .87 & .80 & .94 & .97 & .044 \\
\hline
\end{tabular}

Source: Own elaboration

Table 3. Correlation matrix, and means and standard deviation of the model fitting

\begin{tabular}{|c|c|c|c|c|c|c|c|}
\hline Ethical leadership & .42 & .62 & & & & & \\
\hline interactive justice & .63 & .41 & .46 & .60 & & & \\
\hline Procedural justice & .37 & .59 & .54 & .39 & .52 & & \\
\hline Distributive justice & .37 & .59 & .58 & .50 & .40 & .45 & \\
\hline Means & 19.35 & 19.54 & 17.46 & 18.07 & 13.74 & 25.41 & 15.64 \\
\hline Standard deviation & 5.21 & 4.29 & 3.66 & 4.38 & 4.19 & 5.38 & 5.35 \\
\hline
\end{tabular}

Source: Own elaboration

\section{Discussion}

The objective of this exploration was to examine the relationship between organizational justice, ethical leadership and trust in the organization. The findings of this analysis have different basic consequences. This investigation was one of single a handful few to contain ethical leadership, three parts of justice distributive, procedural and interactional, and trust in the organization in a show.

The main tried utilized the predicted relationship, while the second set was to fit and stated the discoveries. The consequences of this investigation uncovered the critical part that organizational justice plays representative's discernment and the level of the ethical leadership and trust in the organization they got.

The exploration has stated and extended the findings and revealed of the earlier. Ethical leadership has seen worked as mediation between justice and trust in the organization. While supports earlier research. The 
consequences of the investigation to help previous investigations of judges in that fairness is more related trust (J. B. DeConinck, 2010; Stinglhamber et al., 2006).

The outcomes of this examination has shown an imperative part of distributive decency in the view of representatives of ethical and trust, equity of distributive is connected to the specifically to confide in organization and in a roundabout way to trust through ethical leadership, additionally distributive equity is critical develop impact supporter's apparent ethical leadership and trust and, subsequently ought to be incorporated into future research breaking down with various factors, while procedural justice is connected directly to trust in the organization and through ethical leadership.

Interactional justice includes the view of representatives by got the reasonable and treatment of the management. Especially, this investigation tried the worker's view of information and giving that among evaluation of execution in regards to the behavior.

Based on these discoveries in term to limit the interactional decency, the worker must see that the examination was done in an opportune way. Last, the implementation, evaluation should be made-to-order to meet the particular needs of the representative.

\section{Limitation of the Study and Future Research}

This exploration has given different open doors for future investigation, first this examination includes the measures organizational justice, ethical leadership, and trust, future examination requires to duplicate in others think about. Here it revealed both assured and strife other outcomes. For this situation is particularly critical and equity it affects the trust in the organization (Stinglhamber et al., 2006).

One ground could be incorporated into the examination is another leadership style such as (LMX) and investigate it is related to trust and organizational justice. A few inquiries about have notices that equity and leader-member exchange are coordinated (Cohen-Charash \& Spector, 2001; Dulac, Coyle-Shapiro, Henderson, \& Wayne, 2008).

In addition, infrequently has done includes trust and justice in their model including LMX. Other than that, was regard to the trust (Dirks \& Ferrin, 2002), were featured that the relationships among both and transformational and exchange administration. In this manner, either includes saw support or trust must contain in a system, may these acts as intercedes between LMX and result. As appeared in past outcomes uncovered a high connection between that builds, imperative and necessities to exist look at the show include LMX, organizational justice and trust.

As a result, the discoveries of this exploration have shown up that the ethical leadership intervenes the relationship between justice form and trust. Also, a few signs of organizational justice have impacts on trust through ethical leadership. Substantially other not analyzed in this exploration, for example, past investigation demonstrated that exceptionally most noteworthy trust is prompting basic and urgent fulfillment, duty, citizenship conduct and reduces turnover expectations. Subsequently to comprehended the reasons that how subordinates limit the belief it is so basic and critical for the organization. The discoveries have given extra consideration for the view of organizational decency that would help the organization to improve saw of ethical leadership and trust among their workers.

\section{References}

1. Adams, J. S. (1965). Inequity in social exchange. Advances in experimental social psychology, 9, 91-131.

2. Al Halbusi, H., \& Tehseen, S., \& Ramayah, T. (2017). The Impact of Organizational Justice on the Ethical Leadership under the Moderating Influence of Perceived Support: A Conceptual Study. Malaysian Journal of Business and Economics (MJBE), 4(1), 46-64.

3. Aryee, S., \& Chen, Z. X. (2004). Countering the trend towards careerist orientation in the age of downsizing: Test of a social exchange model. Journal of Business Research, 57(4), 321.

4. Aryee, S., Budhwar, P. S., \& Chen, Z. X. (2002). Trust as a mediator of the relationship between organizational justice and work outcomes: Test of a social exchange model. Journal of organizational Behavior, 23(3), 267-285.

5. Bal, P. M., de Lange, A. H., Ybema, J. F., Jansen, P. G., \& van der Velde, M. E. (2011). Age and trust as moderators in the relation between procedural justice and turnover: A large-scale longitudinal study. Applied Psychology, 60(1), 66-86.

6. Bass Bernard, M. (1985). Leadership and Performance Beyond Expectations: New York: A Division of Macmillian: Inc. 
7. Bies, R. J. (1986). Interactional justice The Oxford Handbook of Justice in the Workplace. Blau.

8. Brashear, T. G., Manolis, C., \& Brooks, C. M. (2005). The effects of control, trust, and justice on salesperson turnover. Journal of Business Research, 58(3), 241-249.

9. Brockner, J. (1996). Understanding the interaction between procedural and distributive justice: The role of trust. Journal of Business Ethics, 126(2), 273-284.

10.Brown, M. E., Treviño, L. K., \& Harrison, D. A. (2005). Ethical leadership: A social learning perspective for construct development and testing. Organizational behavior and human decision processes, 97(2), 117-134.

11.Camerman, J., Cropanzano, R., \& Vandenberghe, C. (2007). The benefits of justice for temporary workers. Group \& Organization Management, 32(2), 176-207.

12.Cohen-Charash, Y., \& Spector, P. E. (2001). The role of justice in organizations: A metaanalysis. Organizational behavior and human decision processes, 86(2), 278-321.

13.Colquitt, J. A., Conlon, D. E., Wesson, M. J., Porter, C. O., \& Ng, K. Y. (2001). Justice at the millennium: a meta-analytic review of 25 years of organizational justice research: Correlates and construct issues: American Psychological Association.

14.Cropanzano, R., \& Greenberg, J. (1997). Progress in organizational justice: Tunneling through the maze. International review of industrial and organizational psychology, 12, 317-372.

15.Cropanzano, R., Prehar, C. A., \& Chen, P. Y. (2002). Using social exchange theory to distinguish procedural from interactional justice. Group \& Organization Management, 58(7), 874-882.

16. DeConinck, J. B., \& Stilwell, C. D. (2004). Incorporating organizational justice, role states, pay satisfaction and supervisor satisfaction in a model of turnover intentions. Journal of Business Research, 58(7), 874-882.

17.DeConinck, J., \& Bachmann, D. (2005). An analysis of turnover among retail buyers. Journal of Business Research, 58(7), 874-882.

18.Demirtas, O. (2015). Ethical leadership influence at organizations: Evidence from the field.

19.Dirks, K. T., \& Ferrin, D. L. (2001). The role of trust in organizational settings. Organization science, 12(4), 450-467.

20.Dirks, K. T., \& Ferrin, D. L. (2002). Trust in leadership: meta-analytic findings and implications for research and practice: American Psychological Association.

21.Dulac, T., Coyle-Shapiro, J. A., Henderson, D. J., \& Wayne, S. J. (2008). Not all responses to breach are the same: The interconnection of social exchange and psychological contract processes in organizations. Academy of management Journal, 51(6), 1079-1098.

22.Folger, R., \& Greenberg, J. (1985). Procedural justice: An interpretive analysis of personnel systems. Research in personnel and human resources management, 3(1), 141-183.

23.Folger, R., \& Konovsky, M. A. (1989). Effects of procedural and distributive justice on reactions to pay raise decisions. Academy of management Journal, 32(1), 115-130.

24.Gerstner, C. R., \& Day, D. V. (1997). Meta-Analytic review of leader-member exchange theory: Correlates and construct issues. Journal of applied psychology, 82(6), 827.

25.Gini, A. (1997). Moral leadership and business ethics. Journal of Leadership Studies, 4(4), 64-81.

26.Gounaris, S. P. (2005). Trust and commitment influences on customer retention: insights from business-tobusiness services. Journal of Business Research, 58(2), 126-140.

27.Graen, G., \& Cashman, J. F. (1975). A role-making model of leadership in formal organizations: A developmental approach. Leadership frontiers, 143, 165.

28.Homans, G. C. (1958). Social behavior as exchange. American journal of sociology, 63(6), 597-606.

29.Hoy, W. K., \& Tarter, C. J. (2004). Organizational justice in schools: No justice without trust. Human relations, 56(1), 5-37.

30.Hwa, M. A. C., \& Ramayah, T. (2010). An Empirical Assessment of the Role of Organizational Citizenship Behavior in Explaining Academic Success: Some Evidence from East Malaysian Sample. Gadjah Mada International Journal of Business, 12(1), 55-74.

31.Johnson, J. T., Barksdale, H. C., \& Boles, J. S. (2003). Factors associated with customer willingness to refer leads to salespeople. Journal of Business Research, 56(4), 257-263.

32.Kirkman, B. L., Chen, G., Farh, J.-L., Chen, Z. X., \& Lowe, K. B. (2009). Individual power distance orientation and follower reactions to transformational leaders: A cross-level, cross-cultural examination. Academy of management Journal, 52(4), 744-764.

33.Konovsky, M. A., \& Pugh, S. D. (1994). Citizenship behavior and social exchange. Academy of management Journal, 37(3), 656-669.

34.Li, C., Wu, K., Johnson, D. E., \& Wu, M. (2012). Moral leadership and psychological empowerment in China. Journal of Managerial Psychology, 27(1), 90-108. 
35.Li, Y., Xu, J., Tu, Y., \& Lu, X. (2014). Ethical leadership and subordinates' occupational wellbeing: A multi-level examination in China. Social Indicators Research, 116(3), 823-842.

36.Liden, R. C., \& Graen, G. (1980). Generalizability of the vertical dyad linkage model of leadership. Academy of management Journal, 23(3), 451-465.

37.Lind, E. A., Tyler, T. R., \& Huo, Y. J. (1997). Procedural context and culture: Variation in the antecedents of procedural justice judgments. Journal of personality and social psychology, 73(4), 767.

38.Loi, R., Lam, L. W., \& Chan, K. W. (2012). Coping with job insecurity: The role of procedural justice, ethical leadership and power distance orientation. Journal of Business Ethics, 44(2), 93-107.

39.Loi, R., Yang, J., \& Diefendorff, J. M. (2009). Four-factor justice and daily job satisfaction: a Management, 31(4), 442-468.

40.Mansour-Cole, D. M., \& Scott, S. G. (1998). Hearing It Through The Grapevine: The Influence Of Source, Leader-Relations, And Legitimacy on Survivors 'fairness Perceptions. Personnel Psychology, 51(1), 25-54.

41.Masterson, S. S., Lewis, K., Goldman, B. M., \& Taylor, M. S. (2000). Integrating justice and social exchange: The differing effects of fair procedures and treatment on work relationships. Academy of management Journal, 43(4), 738-748.

42.Mayer, R. C., Davis, J. H., \& Schoorman, F. D. (1995). An integrative model of organizational trust. Academy of management review, 20(3), 709-734.

43.Olkkonen, M.-E., \& Lipponen, J. (2006). Relationships between organizational justice, identification with organization and work unit, and group-related outcomes. Organizational behavior and human decision processes, $100(2), 202-215$.

44.Pappas, J. M., \& Flaherty, K. E. (2008). The effect of trust on customer contact personnel strategic behavior and sales performance in a service environment. Journal of Business 59(5), 582-588.

45.Pillai, R., Schriesheim, C. A., \& Williams, E. S. (1999). Fairness perceptions and trust as mediators for transformational and transactional leadership: A two-sample study. Journal of management, 25(6), 897-933.

46.Rhoades, L., \& Eisenberger, R. (2002). Perceived organizational support: a review of the literature: American Psychological Association.

47.Richard, O. C., Ismail, K. M., Bhuian, S. N., \& Taylor, E. C. (2009). Mentoring in supervisor-subordinate dyads: Antecedents, consequences, and test of a mediation model of mentorship. Journal of Business Research, 62(11), 1110-1118.

48.Riggle, R. J., Edmondson, D. R., \& Hansen, J. D. (2009). A meta-analysis of the relationship between perceived organizational support and job outcomes: 20 years of research.

49.Robinson, S. L. (1996). Trust and breach of the psychological contract. Administrative science quarterly, 574-599.

50.Roch, S. G., \& Shanock, L. R. (2006). Organizational justice in an exchange framework: Clarifying organizational justice distinctions. Journal of management, 32(2), 299-322.

51.Stinglhamber, F., Cremer, D. D., \& Mercken, L. (2006). Perceived support as a mediator of the relationship between justice and trust: A multiple foci approach. Group \& Organization Management, 31(4), 442-468.

52.Swan, J. E., Bowers, M. R., \& Richardson, L. D. (1999). Customer trust in the salesperson: An integrative review and meta-analysis of the empirical literature. Journal of Business, 62(10), 1027-1030.

53.Tan, H. H., \& Tan, C. S. (2000). Toward the differentiation of trust in supervisor and trust in organization. Genetic, Social, and General Psychology Monographs, 126(2), 241.

54.Thibaut, J. W., \& Kelley, H. H. (1959). The Social Physiology of Groups: New York: John Wiley \& Sons.

55.Thibaut, J. W., \& Walker, L. (1975). Procedural justice: A psychological analysis: L. Erlbaum Associates.

56.Treviño, L. K., Brown, M., \& Hartman, L. P. (2003). A qualitative investigation of perceived executive ethical leadership: Perceptions from inside and outside the executive suite. Human relations, 56(1), 5-37.

57.Tyler, T. R. (1989). The psychology of procedural justice: a test of the group-value model. Journal of personality and social psychology, 57(5), 830.

58.Tyler, T. R. (1994). Psychological models of the justice motive: Antecedents of distributive and procedural justice. Journal of personality and social psychology, 67(5), 850.

59.Valentine, S., Greller, M. M., \& Richtermeyer, S. B. (2006). Employee job response as a function of ethical context and perceived organization support. Journal of Business 62(10), 1027.

60.Wong, Y.-T., Wong, C.-S., \& Ngo, H.-Y. (2012). The effects of trust in organisation and perceived organisational support on organisational citizenship behaviour: A test of three competing models. The International Journal of Human Resource Management, 23(2), 278-293. 